\title{
Systematic review and meta-analyses of cases and deaths associated with highly pathogenic avian influenza $\mathrm{H} 5 \mathrm{~N} 1$ in humans and poultry
}

\author{
O. Gabriel Fasanmi ${ }^{1,2 *}$, A. Tinuke Laleye ${ }^{3,4}$ and F. Oludayo Fasina ${ }^{5}$ \\ Address: ${ }^{1}$ Department of Production Animal Studies, Faculty of Veterinary Science, University of Pretoria, Pretoria, South Africa. \\ ${ }^{2}$ Department of Animal Health, Federal College of Animal Health and Production Technology, Ibadan, Nigeria. ${ }^{3}$ Department of \\ Zoology and Entomology, University of Pretoria, Hatfield, South Africa. ${ }^{4}$ National Veterinary Research Institute, Vom, Plateau State, \\ Nigeria. ${ }^{5}$ Department of Veterinary Tropical Diseases, Faculty of Veterinary Science, University of Pretoria, South Africa.
}

*Correspondence: O. Gabriel Fasanmi. Email: bumaetal@gmail.com

Received: $\quad 13$ November 2015

Accepted: $\quad 4$ January 2016

doi: 10.1079/PAVSNNR20161104

The electronic version of this article is the definitive one. It is located here: http://www.cabi.org/cabreviews

(C) CAB International 2016 (Online ISSN 1749-8848)

\begin{abstract}
From 2003 to date (2015), confirmed highly pathogenic avian influenza (HPAI) H5N1 outbreaks in poultry and humans have been reported, however, certain quantitative parameters remain lacking. We obtained 846 reports of HPAI H5N1 outbreaks in poultry in Africa (2006-2015), and 844 reports in humans globally (2003-2015) from different databases. Data were filtered and analysed using meta-analyses. The outputs were generated for each country included in the study and for overall morbidities, mortalities and case fatalities (for poultry and humans). Approximately 11.6 million poultry were included in the analyses as susceptible with 1.9 million cases and 1.7 million deaths in poultry. In humans, 449 deaths were linked to influenza A H5N1 infections. For all poultry outbreaks in 2006-2015 in Africa, an overall mean apparent morbidity of 48.7\% ( $n=1850589)$ was estimated, with overall mean apparent mortality being $40.2 \%(n=1705388)$ and overall mean case fatality rate (CFR) for HPAI H5N1 outbreaks in poultry being $86.4 \%$ $(n=1705388)$. In humans, the overall mean CFR for A H5N1 globally for 2003-2015 was $62.3 \%$ $(n=449)$. Indonesia, Egypt and Vietnam had higher proportions of all human deaths associated with the A H5N1 and Egypt had a significant age-sex bias. Improved reporting and effective quantitation remain key to understanding the characteristics of the virus.
\end{abstract}

Keywords: Case fatality Rate, HPAI H5N1, Humans, Poultry, Meta-analyses

\section{Introduction}

African countries have experienced multiple outbreaks of highly pathogenic avian influenza (HPAl) H5N1 from 2006 [1], and to date 12 African countries have been infected [2, 3]. HPAI H5N1 outbreaks have caused an alarming endemic situation in parts of Africa (especially Egypt) and Asia (Bangladesh, China, Indonesia, Vietnam and eastern India) [4], and other parts of Africa have had infections and re-infections (Nigeria, Cote d'Ivoire, Ghana, Libya, Burkina Faso, Togo and Benin) [3]. To date, only a few countries have reported single or unrelated HPAI H5N1 outbreaks in Africa including Cameroon, Djibouti and Niger [3]. In 2015 alone, outbreaks of avian influenza $(\mathrm{H} 5 \mathrm{~N} 1, \mathrm{H} 5 \mathrm{~N} 2, \mathrm{H} 5 \mathrm{~N} 3, \mathrm{H} 5 \mathrm{~N} 6, \mathrm{H} 5 \mathrm{~N} 1, \mathrm{H} 7 \mathrm{~N} 3$ and
H7N7) were reported in 32 countries including 6 from Africa (Burkina Faso, Cote d'Ivoire, Ghana, Libya, Niger and Nigeria) [3].

In addition to outbreaks in poultry, transmission to humans has been reported worldwide [5, 6]. As of September 2015, a total of 844 confirmed cases with 449 deaths (cumulative proportion of fatal cases: $53.2 \%$ ) of $\mathrm{H} 5 \mathrm{~N} 1$-infected patients had been reported to the World Health Organization from 16 countries [7]. Routine surveillance, either passive or active, is an integral part of the means for detecting cases of HPAI H5N1 outbreak as early as possible $[8,9]$. However, it is unlikely that continuous and sustained surveillance is practiced in parts of Africa where competition for limited resources is great and priorities are often weighed in 
favour of other competing interests apart from animal health and welfare.

Reports of HPAI H5N1, and also other influenza outbreaks in animals and humans, are routinely submitted to international organizations and held by national agricultural and health authorities. Nevertheless, these may not be comprehensive enough, due to, e.g., differences in capacities of human health and veterinary services, and censorship [10]. However, for predictive modelling, disease control, policy decisions and to understand the characteristics of the infectious pathogens, certain parameters such as the actual case morbidity and fatality in poultry and humans will have to be determined. However, to date these data are lacking in peer-reviewed literature. This study was therefore designed to determine the apparent morbidity, apparent mortality, true case fatality rate (CFR) (for both poultry and humans) of avian influenza $\mathrm{H} 5 \mathrm{~N} 1$ in Africa and to assess how interventions affect the situation of fatality in poultry and humans.

\section{Methodology}

\section{Data gathering and generation}

Up-to-date aggregate data were extracted and compiled from the databases and websites of the World Organization for Animal Health [3], World Health Organization [7] and the Food and Agriculture Organization EMPRES-i websites [2]. Data were cross-matched with records in the repository of the national agricultural authorities (where available) or with peer-reviewed studies. Data were quality-checked using filtration to remove duplicates and non-validated data. For a situation of HPAI H5N1 infection to qualify as a case, it was checked that laboratory confirmation [serology, virus isolation, reverse transcription-polymerase chain reaction (RT-PCR)] had been conducted to support suspicion based on the documented report from the authorities. A single case in poultry was considered an outbreak if a single or group of poultry was kept together in a single location at a unit time, but a case in humans was counted on an individual basis [11]. A total of 846 reports of HPAI H5N1 outbreaks in poultry in Africa, and 844 reports for confirmed HPAI H5N1 human infection cases globally, were entered and used for this study. All reported cases were harmonized into a single Microsoft Excel spreadsheet and only validated quantitative data were used.

\section{Statistics}

The data included the number of birds that were susceptible, the number of actual cases and deaths recorded per outbreak per year and per country. Apparent morbidity, apparent mortality and case fatality for the HPAI H5N1 outbreak in poultry in Africa were calculated based on the above data. Similarly, data (cases and deaths) on influenza $A \mathrm{H} 5 \mathrm{~N} 1$ infections in humans globally in 2003-2015 were collected. All data were analysed using the fixed-effect model (precision-based estimates) in the Meta-analyses software of Excel [12]. Comparisons between individual studies were calculated in WinPepi v11.24 [13]. The outputs were generated as countrybased morbidity, mortality and case fatality with $95 \%$ confidence intervals. Cumulative events for apparent morbidity, mortality and case fatality for humans and poultry were also produced in forest plots with measures of central tendencies.

\section{Results}

During this period of outbreaks of HPAl H5N1 (2006-2015) in Africa, approximately 11.6 million poultry were reported as susceptible, 1.9 million cases were documented and 1.7 million deaths of poultry were recorded. Globally, 844 cases and 449 deaths linked to influenza A H5N1 infections were recorded in humans.

For the study period 2006-2008, Burkina Faso was the country with the highest apparent morbidity in Africa (100.0\%; $n=130)$, followed by Cameroon (86.2\%; $n=50)$ and Niger (9.6\%; $n=2700$ ) (Table 1). In the 2014-2015 outbreaks, the highest apparent morbidity was recorded in Cote d'lvoire (98.7\%; $n=51555)$, followed by Burkina Faso (64.2\%; $n=143163)$ and the least apparent morbidity was observed in Nigeria $(10.0 \% ; n=95334)$ (Table 1). For all the outbreaks in 2006-2015, an overall mean apparent morbidity of $48.7 \% \quad\left(\mathrm{Cl}_{95 \%}\right.$ : 47.8-49.6) was estimated $(n=1850589)$ (Table 1, Figure 1, Appendix 1a).

Similarly, the highest apparent mortality for 2006-2008 was recorded in Burkina Faso $(94.6 \% ; n=123)$, followed by Cameroon (86.2\%; $n=50)$ and lowest mortality was reported in Niger (9.0\%; $n=2530)$. In the epidemic period of 2014-2015, Burkina Faso (63.8\%; $n=142246)$, Cote d'lvoire (58.1\%; $n=30335)$ and Nigeria $(9.7 \%$; $n=92312$ ) reported apparent mortality (Table 2). The overall mean apparent mortality was $40.2 \%$ (Cl95\%: 39.3-41.1; $n=1705388$ ) (Table 2, Figure 2, Appendix 1b).

The overall mean CFR for HPAI H5N1 outbreaks in poultry in Africa between 2006 and 2015 was $86.4 \%$ ( $\mathrm{Cl}_{95 \%}$ : 85.5-87.3; $n=1705$ 388). Country-specific CFRs for the epidemic periods 2006-2008 and 2014-2015 were about $100 \%$ for most countries including Djibouti, Cameroon, Egypt, Ghana, Burkina Faso, Sudan and Togo (Table 3, Figure 3, Appendix 1c). However, Cote d'lvoire had a CFR of $39.4 \%$. By far, Egypt had the highest proportions of poultry morbidity (58.3\%), mortality (63.0\%) and case fatality (63.0\%) in Africa Figure 4.

With regards to cases of human fatalities globally, the overall mean CFR for influenza A H5N1 in humans across the globe in 2003-2015 was 62.3\% ( $\mathrm{Cl}_{95 \%}$ : 61.3-63.2; 

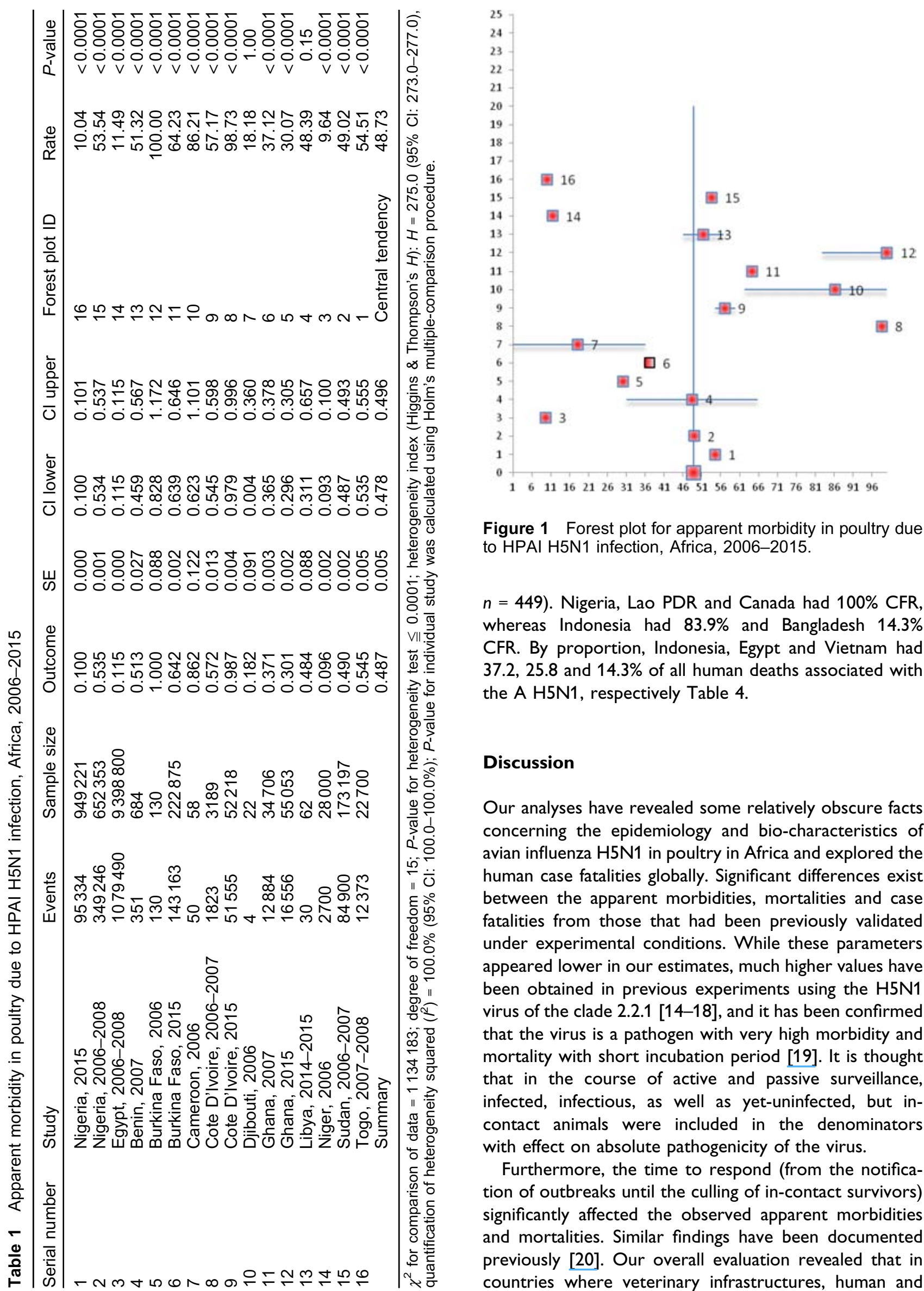

Figure 1 Forest plot for apparent morbidity in poultry due to HPAI H5N1 infection, Africa, 2006-2015.

$n=449)$. Nigeria, Lao PDR and Canada had 100\% CFR, whereas Indonesia had $83.9 \%$ and Bangladesh $14.3 \%$ CFR. By proportion, Indonesia, Egypt and Vietnam had $37.2,25.8$ and $14.3 \%$ of all human deaths associated with the A H5N1, respectively Table 4.

\section{Discussion}

Our analyses have revealed some relatively obscure facts concerning the epidemiology and bio-characteristics of avian influenza $\mathrm{H} 5 \mathrm{~N} 1$ in poultry in Africa and explored the human case fatalities globally. Significant differences exist between the apparent morbidities, mortalities and case fatalities from those that had been previously validated under experimental conditions. While these parameters appeared lower in our estimates, much higher values have been obtained in previous experiments using the H5N1 virus of the clade 2.2.1 [14-18], and it has been confirmed that the virus is a pathogen with very high morbidity and mortality with short incubation period [19]. It is thought that in the course of active and passive surveillance, infected, infectious, as well as yet-uninfected, but incontact animals were included in the denominators with effect on absolute pathogenicity of the virus.

Furthermore, the time to respond (from the notification of outbreaks until the culling of in-contact survivors) significantly affected the observed apparent morbidities and mortalities. Similar findings have been documented previously [20]. Our overall evaluation revealed that in countries where veterinary infrastructures, human and 
Table 2 Apparent mortality in poultry due to HPAI H5N1 infection, Africa, 2006-2015

\begin{tabular}{|c|c|c|c|c|c|c|c|c|c|c|}
\hline Serial number & Study & Events & Sample size & Outcome & SE & $\mathrm{Cl}$ lower & Cl upper & Forest plot ID & Rate & $P$-value \\
\hline 1 & Nigeria, 2015 & 92312 & 949221 & 0.097 & 0.000 & 0.097 & 0.098 & 16 & 9.73 & $<0.0001$ \\
\hline 2 & Nigeria, 2006-2008 & 236850 & 652353 & 0.363 & 0.001 & 0.362 & 0.365 & 15 & 36.31 & $<0.0001$ \\
\hline 3 & Egypt, 2006-2008 & 1073621 & 9398800 & 0.114 & 0.000 & 0.114 & 0.114 & 14 & 11.42 & $<0.0001$ \\
\hline 4 & Benin, 2007 & 180 & 684 & 0.263 & 0.020 & 0.225 & 0.302 & 13 & 26.32 & 0.03 \\
\hline 5 & Burkina Faso, 2006 & 123 & 130 & 0.946 & 0.085 & 0.779 & 1.113 & 12 & 94.62 & $<0.0001$ \\
\hline 6 & Burkina Faso, 2015 & 142246 & 222875 & 0.638 & 0.002 & 0.635 & 0.642 & 11 & 63.82 & $<0.0001$ \\
\hline 7 & Cameroon, 2006 & 50 & 58 & 0.862 & 0.122 & 0.623 & 1.101 & 10 & 86.21 & $<0.0001$ \\
\hline 8 & Cote D'Ivoire, 2006-2007 & 719 & 3189 & 0.225 & 0.008 & 0.209 & 0.242 & 9 & 22.55 & $<0.0001$ \\
\hline 9 & Cote D'Ivoire, 2015 & 30335 & 52218 & 0.581 & 0.003 & 0.574 & 0.587 & 8 & 58.09 & $<0.0001$ \\
\hline 10 & Djibouti, 2006 & 4 & 22 & 0.182 & 0.091 & 0.004 & 0.360 & 7 & 18.18 & $<0.0001$ \\
\hline 11 & Ghana, 2007 & 12884 & 34706 & 0.371 & 0.003 & 0.365 & 0.378 & 6 & 37.12 & $<0.0001$ \\
\hline 12 & Ghana, 2015 & 16238 & 55053 & 0.295 & 0.002 & 0.290 & 0.299 & 5 & 29.50 & $<0.0001$ \\
\hline 13 & Libya, 2014-2015 & 23 & 62 & 0.371 & 0.077 & 0.219 & 0.523 & 4 & 37.10 & 0.75 \\
\hline 14 & Niger, 2006 & 2530 & 28000 & 0.090 & 0.002 & 0.087 & 0.094 & 3 & 9.04 & $<0.0001$ \\
\hline 15 & Sudan, 2006-2007 & 84900 & 173197 & 0.490 & 0.002 & 0.487 & 0.493 & 2 & 49.02 & $<0.0001$ \\
\hline \multirow[t]{2}{*}{16} & Togo, 2007-2008 & 12373 & 22700 & 0.545 & 0.005 & 0.535 & 0.555 & 1 & 54.51 & $<0.0001$ \\
\hline & Summary & & & 0.402 & 0.005 & 0.393 & 0.411 & Central Tendency & 40.22 & \\
\hline
\end{tabular}

$\chi^{2}$ for comparison of data $=739654$; degree of freedom $=15 ; P$-value for heterogeneity test $\leq 0.0001$; heterogeneity index (Higgins \& Thompson's $H$ ): $H=222.1(95 \%$ Cl: $220.1-224.0)$, quantification of heterogeneity squared $\left(I^{2}\right)=100.0 \%(95 \% \mathrm{Cl}: 100.0-100.0 \%) ; P$-value for individual study was calculated using Holm's multiple-comparison procedure.

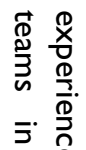

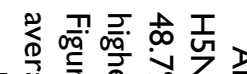

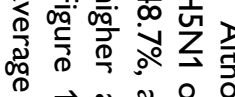

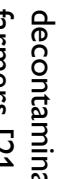

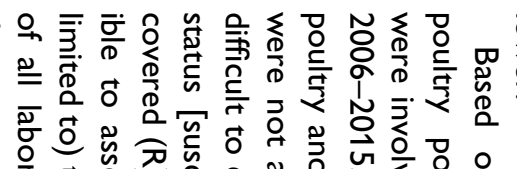
ص

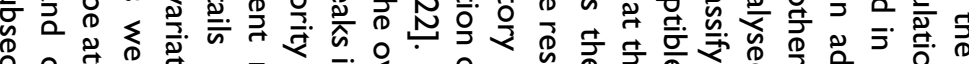

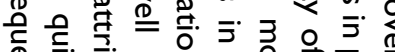

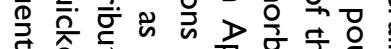

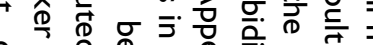

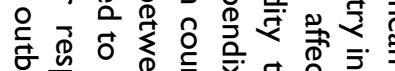

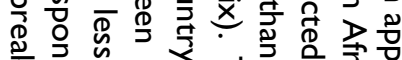

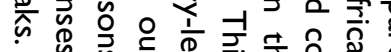

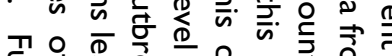

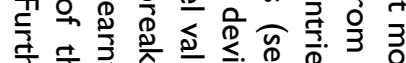

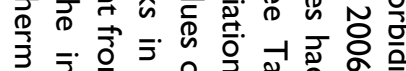

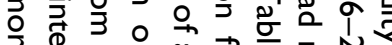

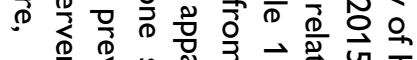
ন.

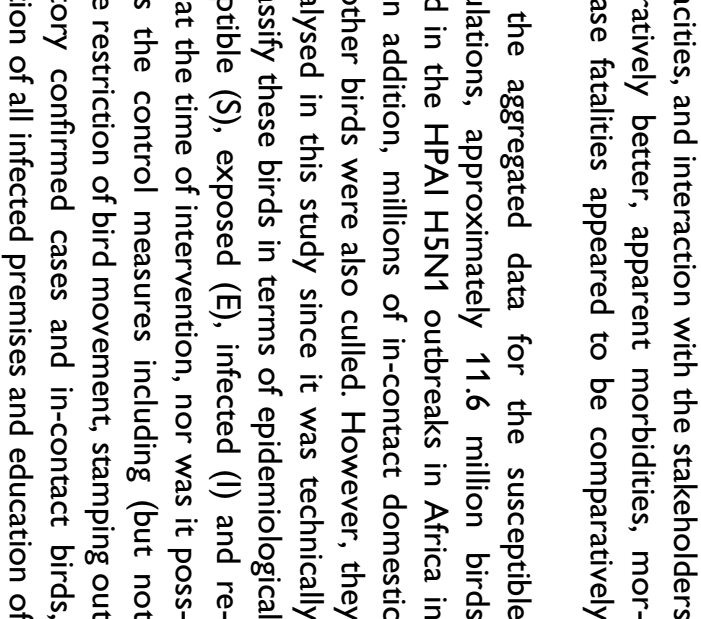

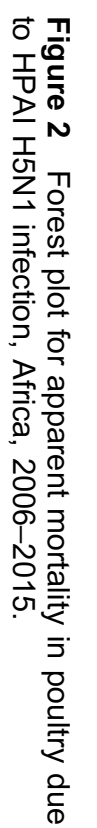

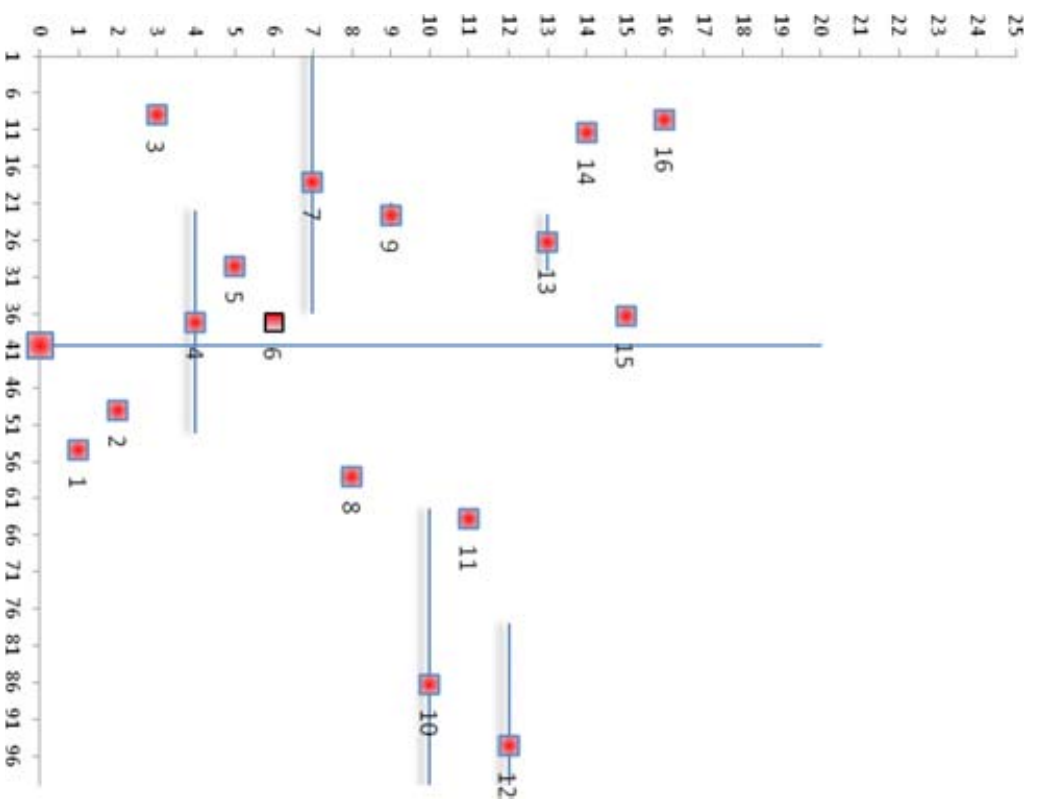
$\mathbb{D}^{0}$ 
Table 3 Case fatality in poultry due to HPAI H5N1 infection, Africa, 2006-2015

\begin{tabular}{|c|c|c|c|c|c|c|c|c|c|c|}
\hline Serial number & Study & Events & Sample size & Outcome & SE & $\mathrm{Cl}$ lower & $\mathrm{Cl}$ upper & Forest plot ID & Rate & $P$-value \\
\hline 1 & Nigeria, 2015 & 92312 & 95334 & 0.968 & 0.003 & 0.962 & 0.975 & 16 & 96.83 & $<0.0001$ \\
\hline 2 & Nigeria, 2006-2008 & 236850 & 349246 & 0.678 & 0.001 & 0.675 & 0.681 & 15 & 67.82 & $<0.0001$ \\
\hline 3 & Egypt, 2006-2008 & 1073621 & 1079490 & 0.995 & 0.001 & 0.993 & 0.996 & 14 & 99.46 & $<0.0001$ \\
\hline 4 & Benin, 2007 & 180 & 351 & 0.513 & 0.038 & 0.438 & 0.588 & 13 & 51.28 & $<0.0001$ \\
\hline 5 & Burkina Faso, 2006 & 123 & 130 & 0.946 & 0.085 & 0.779 & 1.113 & 12 & 94.62 & 1.00 \\
\hline 6 & Burkina Faso, 2015 & 142246 & 143163 & 0.994 & 0.003 & 0.988 & 0.999 & 11 & 99.36 & $<0.0001$ \\
\hline 7 & Cameroon, 2006 & 50 & 50 & 1.000 & 0.141 & 0.723 & 1.277 & 10 & 100.00 & 1.00 \\
\hline 8 & Cote D'Ivoire, 2006-2007 & 719 & 1823 & 0.394 & 0.015 & 0.366 & 0.423 & 9 & 39.44 & $<0.0001$ \\
\hline 9 & Cote D'Ivoire, 2015 & 30335 & 51555 & 0.588 & 0.003 & 0.582 & 0.595 & 8 & 58.84 & $<0.0001$ \\
\hline 10 & Djibouti, 2006 & 4 & 4 & 1.000 & 0.500 & 0.020 & 1.980 & 7 & 100.00 & 1.00 \\
\hline 11 & Ghana, 2007 & 12884 & 12884 & 1.000 & 0.009 & 0.983 & 1.017 & 6 & 100.00 & $<0.0001$ \\
\hline 12 & Ghana, 2015 & 16238 & 16556 & 0.981 & 0.008 & 0.966 & 0.996 & 5 & 98.08 & $<0.0001$ \\
\hline 13 & Libya, 2014-2015 & 23 & 30 & 0.767 & 0.160 & 0.453 & 1.080 & 4 & 76.67 & 1.00 \\
\hline 14 & Niger, 2006 & 2530 & 2700 & 0.937 & 0.019 & 0.901 & 0.974 & 3 & 93.70 & 1.00 \\
\hline 15 & Sudan, 2006-2007 & 84900 & 84900 & 1.000 & 0.003 & 0.993 & 1.007 & 2 & 100.00 & $<0.0001$ \\
\hline \multirow[t]{2}{*}{16} & Togo, 2007-2008 & 12373 & 12373 & 1.000 & 0.009 & 0.982 & 1.018 & 1 & 100.00 & $<0.0001$ \\
\hline & Summary & & & 0.860 & 0.005 & 0.851 & 0.869 & Central tendency & 86.01 & \\
\hline
\end{tabular}

$\chi^{2}$ for comparison of data $=36786$; degree of freedom $=15 ; P$-value for heterogeneity test $\leq 0.0001$; heterogeneity index (Higgins \& Thompson's $H$ ): $H=49.5(95 \%$ Cl: $48.1-51.0$ ), quantification of heterogeneity squared $\left(I^{2}\right)=100.0 \%(95 \% \mathrm{Cl}: 100.0-100.0 \%)$; $P$-value for individual study was calculated using Holm's multiple-comparison procedure.

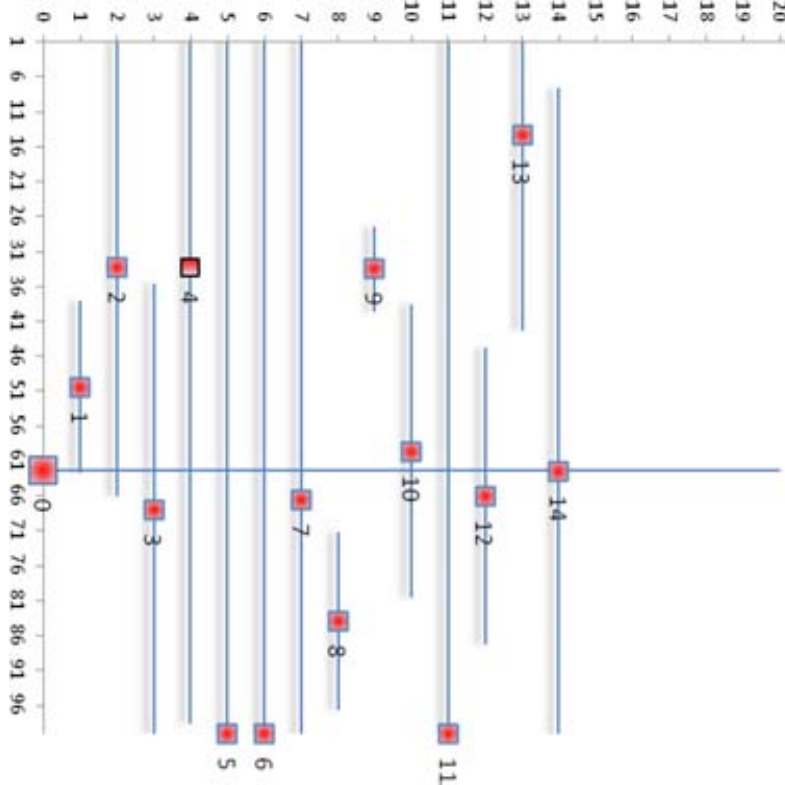


Table 4 Case fatality in humans due to HPAI H5N1 infection globally, 2006-2015

\begin{tabular}{|c|c|c|c|c|c|c|c|c|c|c|}
\hline Serial number & Study & Events & Sample size & Outcome & SE & $\mathrm{Cl}$ lower & Cl upper & Forest plot ID & Rate & $P$-value \\
\hline 1 & Azerbaijan & 5 & 8 & 0.625 & 0.280 & 0.077 & 1.173 & 14 & 62.50 & 1.00 \\
\hline 2 & Bangladesh & 1 & 7 & 0.143 & 0.143 & -0.137 & 0.423 & 13 & 14.29 & 0.03 \\
\hline 3 & Cambodia & 37 & 56 & 0.661 & 0.109 & 0.448 & 0.874 & 12 & 66.07 & 1.00 \\
\hline 4 & Canada & 1 & 1 & 1.000 & 1.000 & -0.960 & 2.960 & 11 & 100.00 & 0.99 \\
\hline 5 & China & 31 & 52 & 0.596 & 0.107 & 0.386 & 0.806 & 10 & 59.62 & 1.00 \\
\hline 6 & Egypt & 116 & 346 & 0.335 & 0.031 & 0.274 & 0.396 & 9 & 33.53 & $<0.0001$ \\
\hline 7 & Indonesia & 167 & 199 & 0.839 & 0.065 & 0.712 & 0.966 & 8 & 83.92 & $<0.0001$ \\
\hline 8 & Iraq & 2 & 3 & 0.667 & 0.471 & -0.257 & 1.591 & 7 & 66.67 & 1.00 \\
\hline 9 & Lao PDR & 2 & 2 & 1.000 & 0.707 & -0.386 & 2.386 & 6 & 100.00 & 1.00 \\
\hline 10 & Nigeria & 1 & 1 & 1.000 & 1.000 & -0.960 & 2.960 & 5 & 100.00 & 0.99 \\
\hline 11 & Pakistan & 1 & 3 & 0.333 & 0.333 & -0.320 & 0.987 & 4 & 33.33 & 1.00 \\
\hline 12 & Thailand & 17 & 25 & 0.680 & 0.165 & 0.357 & 1.003 & 3 & 68.00 & 1.00 \\
\hline 13 & Turkey & 4 & 12 & 0.333 & 0.167 & 0.007 & 0.660 & 2 & 33.33 & 1.00 \\
\hline \multirow[t]{2}{*}{14} & Vietnam & 64 & 127 & 0.504 & 0.063 & 0.380 & 0.627 & 1 & 50.39 & 1.00 \\
\hline & Summary & & & 0.623 & 0.005 & 0.613 & 0.632 & Central tendency & 62.26 & \\
\hline
\end{tabular}

$\chi^{2}$ for comparison of data $=94.9$; degree of freedom $=13 ; P$-value for heterogeneity test $\leqq 0.0001$; heterogeneity index $($ Higgins $\&$ Thompson's $H$ ): $H=2.7$ (95\% Cl: $2.2-3.4)$, quantification of heterogeneity squared $\left(I^{2}\right)=86.3 \%(95 \% \mathrm{Cl}$ : $78.6-91.2 \%)$; $P$-value for individual study was calculated using Holm's multiple-comparison procedure.

apparent morbidities of 57.2 and $98.7 \%$ were estimated, respectively.

The overall mean apparent mortality for the HPAI H5N1 outbreaks in poultry in Africa was $40.2 \%$, with differing country-level outcomes (Table 2, Figure 2). Specifically, the mean value of apparent mortalities in Nigeria and Burkina Faso dropped significantly during the epidemic periods of 2006-2008 and 2015 ( $P<0.0001)$, however, these values were more than double in Cote d'lvoire. These observed increases in apparent morbidity and mortality may be follow from delays and inconsistencies in intervention, increased mean distances from the central disease coordination and management centres, location of outbreaks and the occurrence of multiple overwhelming outbreaks [24]. For instance, the outbreaks in Cote d'lvoire in 2006 primarily occurred in Abidjan, but in 2015, multiple outbreaks occurred in many localities within about a 5-h drive from Abidjan. Rivas et al. [25] confirmed that such distances can play a role in the dissemination of outbreaks to new locations, and Brown et al. [9] stated that multiple empirically-dispersed disease surveillance and detection centres in each country will assist in facilitating rapid and effective controls of outbreaks. The spatio-temporal dynamics of policy decisions on diseases may have influenced the outcomes of HPAl H5N1 infections in Africa.

The overall mean CFR of HPAI H5N1 outbreaks in poultry in Africa in 2006-2015 was 86.0\%. This is comparable to data from other countries. It is worth noting that in certain countries, outbreaks in poultry have been associated with cases and deaths in infected wild birds [26].

Similarly, due to the zoonotic nature of HPAI H5N1 and increased human-animal interactions, a total of 449 deaths associated with $\mathrm{A} \mathrm{H} 5 \mathrm{~N} 1$ infections have occurred in humans globally in 2003-2015, with an estimated CFR of $62.3 \%$ based on reported cases. Our results are comparable to those of Van Kerkhove et al. [27]. However, Li et al. [28] had earlier argued for a lower estimate of $14-33 \%$ due to uncertainties around reporting, and we agree with this postulation. We are aware that our results may have been influenced and biased due to factors like underreporting (especially in cases with milder symptoms), misclassification of cases and its effects on denominators, and censoring effect from local and national authorities where final outcomes cannot be immediately ascertained. However, we tried to filter all data, remove duplicates and validate records based on laboratory-confirmed cases before including data in the evaluation. A CFR in the range determined by $\mathrm{Li}$ et al. [28] (14-33\%) is high enough to warrant the attention of health authorities in case of an epidemic in humans and for an effective control to be implemented [6,9]. Although the virus is yet to adapt effectively to infect and transmit between humans, it and other forms of influenza viruses continue to threaten humans and livestock [29-32].

Although the CFR for human infections was relatively high and varied from one country to another, some of the observed differences may be attributed to delayed diagnosis, and misdiagnosis with respiratory infections that present similar signs and symptoms [27]. Since avian influenza $\mathrm{H} 5 \mathrm{~N} 1$ and other animal influenza viruses continue to threaten humans, reduced human-animal interactions must be implemented and modern farming methods must consider human health in their management procedures. It should be noted that people in close contact with poultry are at high risk of infections, and the elderly, children and individuals with chronic illnesses have higher risks of developing complications, such as bronchitis and chest infection, which may lead to death. To date, Bangladesh, China, Egypt, part of India, Indonesia and Vietnam are considered endemic for HPAI H5N1 virus $[4,33]$. 
In Egypt, human infection with $\mathrm{H} 5 \mathrm{~N} 1$ avian influenza virus was confirmed in poultry and humans, and the influenza-related human morbi-mortality approached zero towards the end of 2008. However, such trend changed significantly between the end of 2014 and November 2015 with a total of 173 human cases and 53 deaths reported as of November 2015. Particularly between November 2014 and 30 April 2015, a total of 165 human cases were reported and 48 deaths were confirmed by the national health authorities - the highest number of human cases ever reported from any country over a similar period. It is possible that close human-animal interactions that exist in Egypt were responsible for this observation. However, between 2006 and 2015, Egypt still reported some of the lowest overall mortality rates. In addition, Egypt has reported the lowest median age of people infected (6 years) and globally the country also has the highest number of infected young people and females [34, 35].

This work was also subject to some other limitations. Data mining was difficult because good-quality and consistent information was scarce in and the skills of veterinary and human health authorities were varied. Benet et al. [36] have earlier highlighted some limitations to effective circulation of critical epidemiological information in developing countries and aspects affecting disease reporting include: independence of health services, coherence of the decision-making chain, coordination among role players, integration between risk assessment and management, and traceability. Also, some countries suspended further reports to the international organizations like the OIE. For instance, Egypt has suspended regular reports to the OIE since July 2008, a period when endemicity of HPAI H5N1 was declared in Egypt [37], and finally, reports from the national authorities do not sometimes correspond to those officially declared to the OIE.

\section{References}

1. Joannis T, Lombin LH, De Benedictis P, Cattoli G, Capua I. Confirmation of H5N1 avian influenza in Africa. Veterinary Record 2006;158:309-10.

2. Food and Agriculture Organisation of the United Nations-Global Animal Disease Information System (FAO-EMPRES I, 2015). Disease Events Map -H5N1 HPAI (Last 2 years). Available from: URL: http://www.empres-i.fao. org/eipws3g/.

3. World Organisation for Animal Health (OIE). Update on highly pathogenic avian influenza in animals (Type $\mathrm{H} 5$ and $\mathrm{H} 7$ ). Available from: URL: http://www.oie.int/animal-health-in-theworld/update-on-avian-influenza/2015/.

4. Food and Agricultural Organisation of the United Nations: Fifth Report of the Global Programme for the Prevention and Control of highly Pathogenic Avian Influenza, January 2011-January 2012. Available from: URL: http://www.fao.org/docrep/017/i3139e/i3139e.pdf
5. Sims L, Domenech J, Benigno C, Kahn S, Kamata A, Lubroth $\mathrm{J}$, et al. Origin and evolution of highly pathogenic H5N1 avian influenza in Asia. Veterinary Record 2005;157:159.

6. Backer J, van Roermund H, Fischer E, van Asseldonk M, Bergevoet R. Controlling highly pathogenic avian influenza outbreaks: an epidemiological and economic model analysis. Preventive Veterinary Medicine 2015;121:142-50.

7. World Health Organization (WHO). Cumulative number of confirmed human cases for avian influenza $A(\mathrm{H} 5 \mathrm{~N} 1)$ reported to WHO, 2003-2015 Available from: URL: http://www.who.int/influenza/human_animal_interface/ EN_GIP_20151015cumulativeNumberH5N1cases.pdf?ua $=1$.

8. Biswas PK, Christensen JP, Ahmed SS, Das A, Rahman MH, Barua $\mathrm{H}$, et al. Risk for infection with highly pathogenic avian influenza virus (H5N1) in backyard chickens, Bangladesh. Emerging Infectious Diseases 2009;15:1931-6.

9. Brown M, Moore L, McMahon B, Powell D, LaBute M, Hyman JM, et al. Constructing rigorous and broad biosurveilance network for detecting emerging zoonotic outbreaks. PLoS ONE 2015;10(5):e0124037. Doi: 10.1371/journal pone. 0124037

10. FAO. Global programme for the prevention and control of H5N1 Highly Pathogenic Avian Influenza 2008. Available from: URL: ftp://ftp.fao.org/docrep/fao/010/ai380e/ ai380e00.pdf.

11. USDA (United States Department for Agriculture), 2015. Avian influenza testing and diagnostic. Fact sheet April, 2015, pp. 1-2.

12. Neyeloff JL, Fuchs SC, Moreira LB. Meta-analyses and forest plots using a Microsoft excel spreadsheet: step-by-step guide focusing on descriptive data analysis. BMC Research Notes 2012;5:52-0500-5-52.

13. Abramson JH. WINPEPI updated: computer programs for epidemiologists, and their teaching potential. Epidemiologic Perspectives \& Innovations 2011;8:1.

14. Guionie O, Guillou-Cloarec C, Courtois D, Bougeard BS, Amelot M, Jestin V. Experimental infection of Muscovy ducks with highly pathogenic avian influenza virus (H5N1) belonging to clade 2.2. Avian Diseases 2010;54:538-47.

15. Rauw F, Palya V, Gardin Y, Tatar-Kis T, Dorsey KM, Lambrecht $\mathrm{B}$, et al. Efficacy of rHVT-Al vector vaccine in broilers with passive immunity against challenge with two antigenically divergent Egyptian clade 2.2. $1 \mathrm{HPAI}$ H5N1 strains. Avian Diseases 2012;56:913-22.

16. Rauw F, Palya V, Van Borm S, Welby S, Tatar-Kis T, Gardin Y, et al. Further evidence of antigenic drift and protective efficacy afforded by a recombinant HVT-H5 vaccine against challenge with two antigenically divergent Egyptian clade 2.2. $1 \mathrm{HPAl}$ H5N1 strains. Vaccine 2011;29:2590-600.

17. Kilany WH, Khalifa MK, Safwat M, Mohammed S, Selim A, VonDobschuetz $\mathrm{S}$, et al. Comparison of the effectiveness of rHVT-H5, inactivated H5 and rHVT-H5 with inactivated $\mathrm{H} 5$ prime/boost vaccination regimes in commercial broiler chickens carrying MDAs against HPAI H5N1 Clade 2.2. 1 virus challenge. Avian Pathology 2015;44(5):333-41.

18. Kilany W, Dauphin G, Selim A, Tripodi A, Samy M, Sobhy H, et al. Protection conferred by recombinant Turkey herpesvirus avian influenza (rHVT-H5) vaccine in the rearing period in two 
commercial layer chicken breeds in Egypt. Avian Pathology 2014:43:514-23.

19. Peiris JS, de Jong MD, Guan Y. Avian influenza virus (H5N1): a Threat to human health. Clinical Microbiology Reviews 2007:20:243-67.

20. Otte J, Hinrichs J, Rushton J, Roland-Holst D, Zilberman D. Impacts of Avian Influenza Virus on Animal Production in Developing Countries. CAB Reviews: Perspectives in Agriculture, Veterinary Science, Nutrition and Natural Resources 2008;3:18.

21. FAO/OIE. FAO Recommendations on the Prevention, Control and Eradication of Highly Pathogenic Avian Influenza (HPAl) in Asia (proposed with the support of the OIE), September 2004. Available from: URL: http://www.web.oie.int/eng/AVIAN_INFLUENZA/FAO\% 20recommendations $\% 20$ on $\% 20 \mathrm{HPAl}$.pdf

22. Ekong PS, Ducheyne E, Carpenter TE, Owolodun OA, Oladokun AT, Lombin LH, et al. Spatio-temporal epidemiology of highly pathogenic avian influenza (H5N1) outbreaks in Nigeria, 2006-2008. Preventive Veterinary Medicine 2012;103:170-7.

23. Pagani P, Abimiku Y, Emeka-Okolie W. Assessment of the Nigerian poultry market chain to improve biosecurity. FAO (Nigeria, Consultative Mission on Poultry) Study 2008:1-65.

24. Council Directive 2005/94/EC. On community measures for the control of avian influenza and repealing Directive 92/40/ EEC. Official Journal of the European Union, L10/16-L10/65. p. 142-50. Available from: URL: http://eur-lex.europa.eu/legalcontent/EN/TXT/?uri = CELEX:32005L0094.

25. Rivas AL, Chowell G, Schwager S, Fasina FO, Hoogesteijn $\mathrm{AL}$, Smith SD, et al. Lessons from Nigeria: the role of roads in the geo-temporal progression of avian influenza (H5N1) virus. Epidemiology and Infection 2010;138:192-8.

26. Li Y, Liu L, Zhang Y, Duan Z, Tian G, Zeng X, et al. New avian infl uenza virus (H5N1) in wild birds, Qinghai, China. Emerging Infectious Diseases 2011;17(12):265-7.

27. Van Kerkhove MD, Mumford E, Mounts AW, Bresee J, Ly S, Bridges CB, et al. Highly pathogenic avian influenza (H5N1): pathways of exposure at the animal-human interface, a systematic review. PLoS ONE 2011;6:e14582.

28. Li FC, Choi BC, Sly T, Pak AW. Finding the real case-fatality rate of H5N1 avian influenza. Journal of Epidemiology and Community Health 2008;62:555-9.
29. Koopmans M, Wilbrink B, Conyn M, Natrop G, van der Nat H, Vennema $\mathrm{H}$, et al. Transmission of $\mathrm{h} 7 \mathrm{n} 7$ avian influenza a virus to human beings during a large outbreak in commercial poultry farms in the Netherlands. Lancet 2004;363:587-93.

30. Herfst S, Schrauwen EJ, Linster M, Chutinimitkul S, de Wit E, Munster VJ, et al. Airborne transmission of influenza A/H5N1 virus between ferrets. Science 2012;336:1534-41.

31. Cowling BJ, Jin L, Lau EH, Liao Q, Wu $\mathrm{P}$, Jiang $\mathrm{H}$, et al. Comparative epidemiology of human infections with avian influenza A H7N9 and H5N1 viruses in China: a populationbased study of laboratory-confirmed cases. Lancet 2013;382:129-37.

32. Li Q, Wang X, Gao Z, Sun Z, Cui Z, Duan Z, et al. Novel reassortant $\mathrm{H} 5 \mathrm{~N} 5$ viruses bind to a human-type receptor as a Factor in pandemic risk. Veterinary Microbiology 2015;175:356-61.

33. FAO. Approaches to controlling, preventing and eliminating H5N1 Highly Pathogenic Avian Influenza in endemic countries. Animal Production and Health Paper. No. 171. Rome; 2011. p. $1-81$.

34. Fiebig L, Soyka J, Buda S, Buchholz U, Dehnert M, Haas W. Avian influenza A(H5N1) in humans: new insights from a line list of World Health Organization confirmed cases, September 2006 to August 2010. Euro Surveillance 2011;16(32):pii=19941. Available from: URL: http://www.eurosurveillance.org/ViewArticle.aspx? Articleld $=19941$

35. Dudley JP. Age-specific infection and death rates for human $\mathrm{A}(\mathrm{H} 5 \mathrm{~N} 1)$ avian influenza in Egypt. Euro Surveillance 2009;14(18):pii=19198. Available from: URL: http://www. eurosurveillance.org/ViewArticle.aspx?Articleld = 19198.

36. Benet J, Dufour B, Bellemain V. The organisation and functioning of veterinary services: results of a 2005 survey of member countries of the world organisation for animal health. Revue Scientifique et Technique-Office International Des Epizooties 2006;25(2):713-61.

37. OIE. Graph of Outbreaks of Highly Pathogenic Avian Influenza (subtype H5N1) in poultry notified to the OIE * from the end of 2003 to 29 October 2015b. Available from: URL: http://www.oie.int/fileadmin/Home/eng/Animal_Health_in_the _ World/docs/pdf/graph_avian_influenza/graphs_HPAI_ 29 10_2015.pdf 


\section{Appendix 1a.}

Apparent morbidity of HPAI H5N1 in poultry in Africa using 846 reports, 2006-2015.

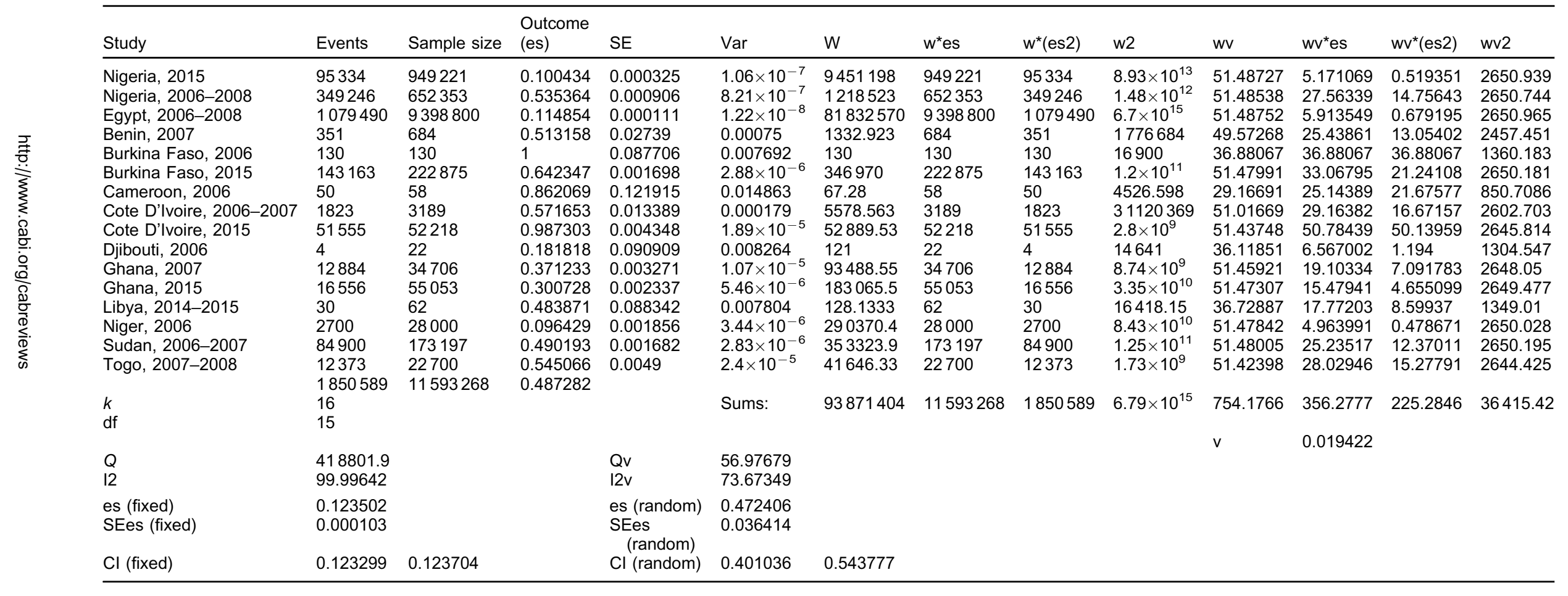




\section{Appendix 1b.}

Apparent mortality of HPAI H5N1 in poultry in Africa using 846 reports, 2006-2015.

\begin{tabular}{|c|c|c|c|c|c|c|c|c|c|c|c|c|c|}
\hline Study & Events & Sample size & $\begin{array}{l}\text { Outcome } \\
\text { (es) }\end{array}$ & SE & Var & w & $w^{*} e s$ & $\mathrm{w}^{*}(\mathrm{es} 2)$ & w2 & wv & $w v^{*} e s$ & $w v^{*}(e s 2)$ & wv2 \\
\hline Nigeria, 2015 & 92312 & 949221 & 0.09725 & 0.00032 & $1.02 \times 10^{-7}$ & 9760600 & 949221 & 92312 & $9.53 \times 10^{13}$ & 78.66748 & 7.650434 & 0.744007 & 6188.573 \\
\hline Nigeria, 2006-2008 & 236850 & 652353 & 0.36307 & 0.000746 & $5.57 \times 10^{-7}$ & 1796768 & 652353 & 236850 & $3.23 \times 10^{12}$ & 78.66467 & 28.56081 & 10.36958 & 6188.131 \\
\hline Egypt, 2006-2008 & 1073621 & 9398800 & 0.11423 & 0.00011 & $1.22 \times 10^{-8}$ & 82279912 & 9398800 & 1073621 & $6.77 \times 10^{15}$ & 78.66804 & 8.986218 & 1.026492 & 6188.661 \\
\hline Benin, 2007 & 180 & 684 & 0.263158 & 0.019615 & 0.000385 & 2599.2 & 684 & 180 & 6755841 & 76.35707 & 20.09397 & 5.287886 & 5830.403 \\
\hline Burkina Faso, 2006 & 123 & 130 & 0.946154 & 0.085312 & 0.007278 & 137.3984 & 130 & 123 & 18878.31 & 50.02567 & 47.33198 & 44.78334 & 2502.568 \\
\hline Burkina Faso, 2015 & 142246 & 222875 & 0.638232 & 0.001692 & $2.86 \times 10^{-6}$ & 349206.8 & 222875 & 142246 & $1.22 \times 10^{11}$ & 78.6504 & 50.19722 & 32.03748 & 6185.885 \\
\hline Cameroon, 2006 & 50 & 58 & 0.862069 & 0.121915 & 0.014863 & 67.28 & 58 & 50 & 4526.598 & 36.26488 & 31.26283 & 26.95071 & 1315.142 \\
\hline Cote D'Ivoire, 2006-2007 & 719 & 3189 & 0.225463 & 0.008408 & $7.07 \times 10^{-5}$ & 14144.26 & 3189 & 719 & $2 \times 10^{8}$ & 78.233 & 17.63861 & 3.976846 & 6120.402 \\
\hline Cote D'Ivoire, 2015 & 30335 & 52218 & 0.58093 & 0.003335 & $1.11 \times 10^{-5}$ & 89886.91 & 52218 & 30335 & $8.08 \times 10^{9}$ & 78.59933 & 45.6607 & 26.52567 & 6177.854 \\
\hline Djibouti, 2006 & 4 & 22 & 0.181818 & 0.090909 & 0.008264 & 121 & 22 & 4 & 14641 & 47.67332 & 8.667877 & 1.575978 & 2272.746 \\
\hline Ghana, 2007 & 12884 & 34706 & 0.371233 & 0.003271 & $1.07 \times 10^{-5}$ & 93488.55 & 34706 & 12884 & $8.74 \times 10^{9}$ & 78.60198 & 29.17962 & 10.83243 & 6178.271 \\
\hline Ghana, 2015 & 16238 & 55053 & 0.294952 & 0.002315 & $5.36 \times 10^{-6}$ & 186650.6 & 55053 & 16238 & $3.48 \times 10^{10}$ & 78.63498 & 23.19355 & 6.840988 & 6183.459 \\
\hline Libya, 2014-2015 & 23 & 62 & 0.370968 & 0.077352 & 0.005983 & 167.1304 & 62 & 23 & 27932.58 & 53.49029 & 19.84317 & 7.361177 & 2861.212 \\
\hline Niger, 2006 & 2530 & 28000 & 0.090357 & 0.001796 & $3.23 \times 10^{-6}$ & 309881.4 & 28000 & 2530 & $9.6 \times 10^{10}$ & 78.64815 & 7.106422 & 0.642116 & 6185.532 \\
\hline Sudan, 2006-2007 & 84900 & 173197 & 0.490193 & 0.001682 & $2.83 \times 10^{-6}$ & 353323.9 & 173197 & 84900 & $1.25 \times 10^{11}$ & 78.65061 & 38.554 & 18.89891 & 6185.918 \\
\hline Togo, 2007-2008 & $\begin{array}{l}12373 \\
1705388\end{array}$ & $\begin{array}{l}22700 \\
11593268\end{array}$ & $\begin{array}{l}0.545066 \\
0.402196\end{array}$ & 0.0049 & $2.4 \times 10^{-5}$ & 41646.33 & 22700 & 12373 & $1.73 \times 10^{9}$ & 78.5198 & 42.79848 & 23.328 & 6165.359 \\
\hline k & 16 & & & & Sums: & 95278601 & 11593268 & 1705388 & $6.87 \times 10^{15}$ & 1128.35 & 426.7259 & 221.1816 & 82730.11 \\
\hline \multirow[t]{2}{*}{$\mathrm{df}$} & 15 & & & & & & & & & & & & \\
\hline & & & & & & & & & & $\mathrm{v}$ & 0.012712 & & \\
\hline Q & 294747.4 & & & Qv & 59.79991 & & & & & & & & \\
\hline 12 & 99.99491 & & & $12 v$ & 74.91635 & & & & & & & & \\
\hline es (fixed) & 0.121678 & & & es (random) & 0.378186 & & & & & & & & \\
\hline SEes (fixed) & 0.000102 & & & SEes (random) & 0.02977 & & & & & & & & \\
\hline $\mathrm{Cl}$ (fixed) & 0.121477 & 0.121878 & & $\mathrm{Cl}$ (random) & 0.319837 & 0.436535 & & & & & & & \\
\hline
\end{tabular}




\section{Appendix 1c.}

Case fatality of HPAI H5N1 in poultry in Africa using 846 reports, 2006-2015.

\begin{tabular}{|c|c|c|c|c|c|c|c|c|c|c|c|c|c|}
\hline Study & Events & Sample size & $\begin{array}{l}\text { Outcome } \\
\text { (es) }\end{array}$ & SE & Var & w & $\mathrm{w}^{*} \mathrm{es}$ & $\mathrm{w}^{*}(\mathrm{es} 2)$ & w2 & wv & $w v^{*} e s$ & $w v^{\star}(e s 2)$ & wv2 \\
\hline Nigeria, 2015 & 92312 & 95334 & 0.968301 & 0.003187 & $1.02 \times 10^{-5}$ & 98454.93 & 95334 & 92312 & $9.69 \times 10^{9}$ & 28.17804 & 27.28482 & 26.41992 & 794.0018 \\
\hline Nigeria, 2006-2008 & 236850 & 349246 & 0.678175 & 0.001393 & $1.94 \times 10^{-6}$ & 514979 & 349246 & 236850 & $2.65 \times 10^{11}$ & 28.18456 & 19.11407 & 12.96269 & 794.3696 \\
\hline Egypt, 2006-2008 & 1073621 & 1079490 & 0.994563 & 0.00096 & $9.21 \times 10^{-7}$ & 1085391 & 1079490 & 1073621 & $1.18 \times 10^{12}$ & 28.18537 & 28.03213 & 27.87973 & 794.4153 \\
\hline Benin, 2007 & 180 & 351 & 0.512821 & 0.038223 & 0.001461 & 684.45 & 351 & 180 & 468471.8 & 27.07129 & 13.88271 & 7.11934 & 732.8548 \\
\hline Burkina Faso, 2006 & 123 & 130 & 0.946154 & 0.085312 & 0.007278 & 137.3984 & 130 & 123 & 18878.31 & 23.38821 & 22.12885 & 20.93729 & 547.0085 \\
\hline Burkina Faso, 2015 & 142246 & 143163 & 0.993595 & 0.002634 & $6.94 \times 10^{-6}$ & 144085.9 & 143163 & 142246 & $2.08 \times 10^{10}$ & 28.18059 & 28.00009 & 27.82074 & 794.1458 \\
\hline Cameroon, 2006 & 50 & 50 & 1 & 0.141421 & 0.02 & 50 & 50 & 50 & 2500 & 18.02501 & 18.02501 & 18.02501 & 324.901 \\
\hline $\begin{array}{l}\text { Cote D'Ivoire, } \\
2006-2007\end{array}$ & 719 & 1823 & 0.394405 & 0.014709 & 0.000216 & 4622.154 & 1823 & 719 & 21364311 & 28.01527 & 11.04936 & 4.35792 & 784.8552 \\
\hline Cote D'Ivoire, 2015 & 30335 & 51555 & 0.588401 & 0.003378 & $1.14 \times 10^{-5}$ & 87618.86 & 51555 & 30335 & $7.68 \times 10^{9}$ & 28.17704 & 16.57939 & 9.755326 & 793.9456 \\
\hline Djibouti, 2006 & 4 & 4 & 1 & 0.5 & 0.25 & 4 & 4 & 4 & & 3.502891 & 3.502891 & 3.502891 & 12.27025 \\
\hline Ghana, 2007 & 12884 & 12884 & & 0.00881 & $7.76 \times 10^{-5}$ & 12884 & 12884 & 12884 & $1.66 \times 10^{8}$ & 28.12458 & 28.12458 & 28.12458 & 790.9919 \\
\hline Ghana, 2015 & 16238 & 16556 & 0.980792 & 0.007697 & $5.92 \times 10^{-5}$ & 16880.23 & 16556 & 16238 & $2.85 \times 10^{8}$ & 28.13912 & 27.59864 & 27.06853 & 791.81 \\
\hline Libya, 2014-2015 & 23 & 30 & 0.766667 & 0.159861 & 0.025556 & 39.13043 & 30 & 23 & 1531.191 & 16.3843 & 12.5613 & 9.630329 & 268.4454 \\
\hline Niger, 2006 & 2530 & 2700 & 0.937037 & 0.018629 & 0.000347 & 2881.423 & 2700 & 2530 & 8302598 & 27.91306 & 26.15557 & 24.50874 & 779.1389 \\
\hline Sudan, 2006-2007 & 84900 & 84900 & & 0.003432 & $1.18 \times 10^{-5}$ & 84900 & 84900 & 84900 & $7.21 \times 10^{9}$ & 28.17675 & 28.17675 & 28.17675 & 793.9293 \\
\hline Togo, 2007-2008 & $\begin{array}{l}12373 \\
1705388\end{array}$ & $\begin{array}{l}12373 \\
1850589\end{array}$ & 1 & 0.00899 & $8.08 \times 10^{-5}$ & 12373 & 12373 & 12373 & $1.53 \times 10^{8}$ & 28.12204 & 28.12204 & 28.12204 & 790.8493 \\
\hline $\begin{array}{l}k \\
d f\end{array}$ & $\begin{array}{l}16 \\
15\end{array}$ & & 0.000001 & & Sums: & 2065986 & 1850589 & 1705388 & $1.49 \times 10^{12}$ & 397.7681 & 338.3382 & 304.4118 & 10587.93 \\
\hline & & & & & & & & & & $v$ & 0.035478 & & \\
\hline $\begin{array}{l}\mathrm{Q} \\
12\end{array}$ & $\begin{array}{l}47738.62 \\
99.96858\end{array}$ & & & $\begin{array}{l}\text { Qv } \\
12 v\end{array}$ & $\begin{array}{l}16.62422 \\
9.770215\end{array}$ & & & & & & & & \\
\hline es (fixed) & 0.895742 & & & es (random) & 0.850592 & & & & & & & & \\
\hline SEes (fixed) & 0.000696 & & & SEes (random) & 0.05014 & & & & & & & & \\
\hline $\mathrm{Cl}$ (fixed) & 0.894378 & 0.897105 & & $\mathrm{Cl}$ (random) & 0.752317 & 0.948866 & & & & & & & \\
\hline
\end{tabular}


Appendix 1d.

Case fatality of HPAI H5N1 in humans using 842 reports, 2006-2015.

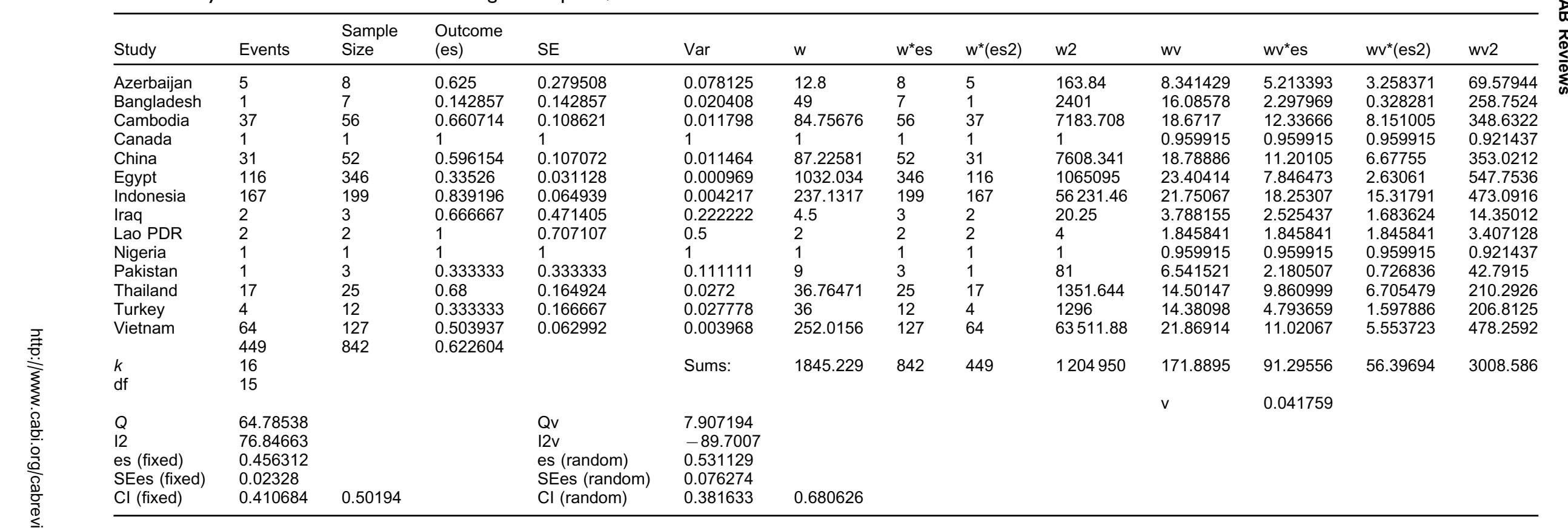

